\title{
EFFECT OF CHEMICAL AND MINERALOGICAL COMPOSITION OF ROCKS ON THE GROUNDWATER CHEMISTRY OF HEWANIE AND ITS SURROUNDING AREAS, SOUTHERN TIGRAY, ETHIOPIA.
}

\author{
Abraha Nigusse $1,{ }^{*}$ Abraham Bairu², Nata Tadesse ${ }^{3}$, and K. Bheemalingeswara ${ }^{3}$ \\ DOI: $\underline{\text { http://dx.doi.org/10.4314/ejesm.v4i4.3 }}$
}

Received November $4^{\text {th }} 2011$; accepted November $21^{\text {st }} 2011$

\begin{abstract}
The study was conducted in Hewanie and its surrounding areas of $169.82 \mathrm{~km}^{2}$ with a major objective of identifying the effect of chemical and mineralogical composition of rocks on the chemistry of the groundwater quality. This was conducted by taking 11 groundwater and 5 rock samples from the main geological units of the study area. Water samples were analyzed for major cations and anions, trace elements, TDS, total hardness, $p H$, electrical conductivity, and alkalinity the rock samples for major cations and anions and trace elements using AAS. The data was used to qualify and assess the quality of groundwater in the study area. Concentration of $\mathrm{Ca}^{2+}, \mathrm{Mg}^{2+}, \mathrm{Na}^{+}, \mathrm{K}^{+}, \mathrm{HCO}_{3}{ }^{-}, \mathrm{Cl}$ and $\mathrm{SO}_{4}^{2-}$ of groundwater samples in $\mathrm{mg} / \mathrm{l}$ varied from 84 to 412, 96 to 211.2, 19.09 to 43.93, 2.34 to 51.09, 244 to 585.6, 71 to 340.8 and 49.49 to 122.5 , respectively. Concentrations of $\mathrm{Ca}^{2+}, \mathrm{Mg}^{2+}, \mathrm{Na}^{+}, \mathrm{K}^{+}, \mathrm{HCO}_{3}^{-}, \mathrm{Cl}^{-}$ and $\mathrm{SO}_{4}{ }^{2-}$ of rock samples in ppm varied from 2586.4 to $28540,2575.8$ to 5289.6, 28.83 to 6134.9, 190.3 to $2379,293.74$ to $3717.6,433.1$ to 1143.1, 2787.8 to 27849.6, respectively. The predominant cations trend in both the groundwater and rock samples the study area was $\mathrm{Ca}^{2+}>\mathrm{Mg}^{2+}>\mathrm{Na}^{+}>\mathrm{K}^{+}$. Therefore, it is concluded that the local rock chemistry is seriously affecting the groundwater chemistry.
\end{abstract}

Key words: Rock-water interaction, groundwater, rock, mineralogical composition, quality, Hewanie, Ethiopia.

\section{Introduction}

Some of the substances that find their way naturally into groundwater are unhealthy to us or to other life forms. Groundwater is essential for human and all other living things as food. In addition to groundwater uses for drinking, humans need groundwater for various other purposes like bathing, washing, and cooking, industrial, agricultural and recreational activities. Thus, the availability of adequate groundwater supply in terms of its quantity and quality is essential for the existence of life. It should be free from pathogensdisease causing microbes and toxic or physiologically undesirable chemicals or biological materials. Groundwater is available in nature in the form of groundwater and surface water. Discharge of wastes poses problem for surface, while seepage of chemicals from dumpsites may affect groundwater depending on the nature of the underlying rocks in the area. Hence, groundwater requires physical, chemical and biological treatment, depending on the nature of existing pollutants, before being supplied for domestic uses .To plan and implement the type and extent of treatment, natural groundwater must be analyzed for physical, chemical and microbiological parameters. After appropriate treatment in a groundwater treatment plant, the quality of groundwater is again tested to ensure its suitability for human consumption. The suitability of groundwater is judged on the basis of modern drinking groundwater standards set up by different governmental and health agencies. Groundwater resource protection is a universal problem for the continued existence of mankind, and the management of this problem requires cooperation between governmental and nongovernmental organizations. The importance of groundwater for man and his environment has been clearly defined in 12 items of the European charter on groundwater declared by European council on May 6, 1948 in Strasbourg (Tolgyessy, 1993).

Inhabitants of Hewanie and its surroundings are predominantly using groundwater for domestic purposes. Water of acceptable quality is scarcely

\footnotetext{
${ }^{1}$ Department of Civil Engineering, Institute of Science and Technology, Ambo University, Ambo, Ethiopia.

${ }^{2}$ Research and Technology Development Directorate, Tigray Science and Technology Agency, Mekelle, Tigray, Ethiopia. Corresponding author email: abrahambairu@ymail.com

${ }^{3}$ Department of Earth Sciences, Mekelle University, Mekelle, Tigray, Ethiopia.
} 
available and hence they are suffering from hardness and salinityo hazards due to the inappropriate concentration of ions in the groundwater. The groundwater quality problems which are observed in the study area may also cause various health problems for the peoples of that area. It is expected that the dissolved solids in the groundwater may exceed the standards, which are set by the World Health Organization (WHO). Therefore, performing the qualitative analysis of this groundwater is vital to recommend solutions. The Tigray Regional Government has also aimed at providing quality groundwater to the people of the region. In line with that an effort present paper tries to address the problems in terms of groundwater quality and help finding solutions.
The results of the investigation conducted in and around Hewanie in Hintalo Wejjerat Wereda, southern Tigray, Ethiopia carried out with an objective of identifying the effect of chemical and mineralogical composition of rocks on the chemistry of the groundwater quality are presented.

\section{Methodology \\ Location}

The study area is geographically located between 1445000 to $1453000 \mathrm{~m} \mathrm{~N}$ and 551000 to $556000 \mathrm{~m}$ E with an aerial extent of $169.82 \mathrm{sq}$. km. The area is surrounded by mountains where the drainage pattern is mainly dense and shows dendritic pattern. The streams generally flow towards the northwestern part (Figure 1).

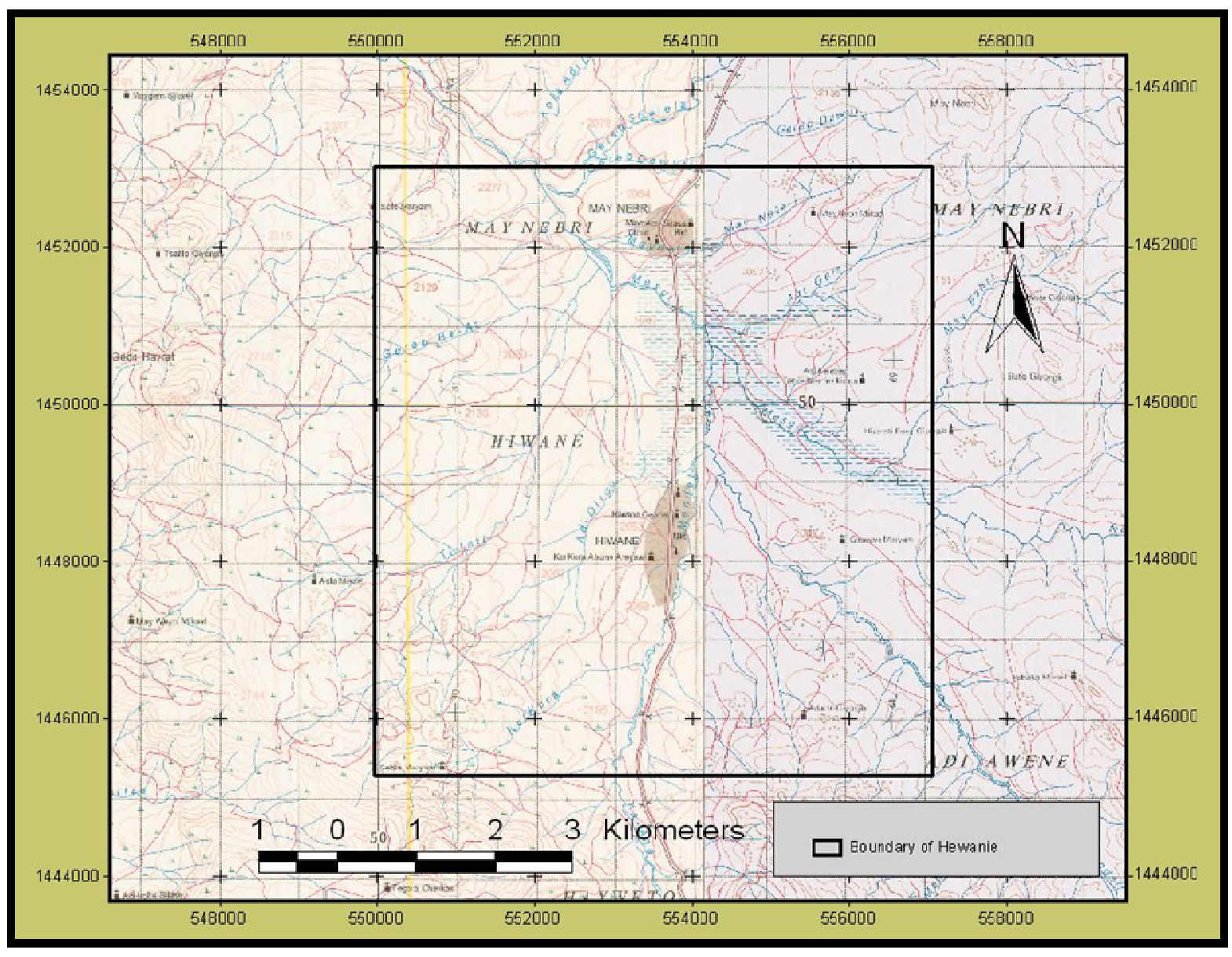

Figure 1 Location map of the study area 


\section{Sampling}

Eleven groundwater and five rock samples were collected from the selected wells and selected main geologic units, respectively. All the groundwater samples were collected in prewashed, numbered two liter plastic bottles using depth integrated sampling techniques. Care was taken not to take stagnant groundwater and also the ones which are protected free from surface water interaction and other surface contaminants. Further, the wells selection, well location and the local rock was also taken into consideration. The rock samples were also taken from the dominant geologic units and fresh samples greater than $1 / 2$ a kilogram were taken in properly numbered plastic bags. The details of groundwater and rock samples are given below.

A total of ten groundwater samples were collected. One sample (MAHP1) from the basalt and shale and limestone intercalation, one sample (KUHP2) from the upper sandstone and limestone contact points, two samples (TSEHP3 and TSEHP4) from the thick Shale and thin limestone, two samples (GBHP5 and SWNT) form the shale and limestone intercalation, one sample (HTHP6) from the alluvial deposit, one sample (BW(FTC)) from the crystalline limestone and two samples (MSGSP1 and MSGSP2) from the micritic limestone. Similarly, one rock sample (MA) from the basalt and shale and limestone intercalation, one rock sample (TS) from the thick Shale and thin limestone, one rock sample (GB) from the shale and limestone intercalation, one rock sample (FTC) from the crystalline limestone and one rock sample (MSG) from micritic limestone totally five rock samples were collected from the study area (Figure 2).

\section{Sample analyses}

These rock samples were powdered, agitated and analyzed for major cations and trace elements $\mathrm{Ca}, \mathrm{Mg}, \mathrm{Na}, \mathrm{K}, \mathrm{Fe}, \mathrm{Mn}, \mathrm{Co}, \mathrm{Cu}, \mathrm{Ni}, \mathrm{Pb}$ and the major anion constituents $\mathrm{Cl}, \mathrm{SO}_{4}$, and $\mathrm{HCO}_{3}$ using Atomic Adsorption Spectrophotometer (AAS) and Ultra Violet Spectrophotometer (UVS) at Ezana Mining Development Analytical Laboratory PLC.
The groundwater samples were also analyzed for major and trace ions. The major cations and anions were analyzed using Atomic Adsorption Spectrophotometer (AAS) and Ultra Violet Spectrophotometer (UVS), respectively by Tigray Agricultural and Rural Development Bureau Soil and Groundwater Laboratory, and the trace cations and anions were detected using Atomic Adsorption Spectrophotometer (AAS) in Ezana Mining Development Analytical Laboratory PLC. as per the standard methods of APHA (2005) and Eaton et al. (1998).

The qualities of the groundwater were assessed in terms of total hardness, total dissolved solids, alkalinity, electrical conductivity $(\mathrm{ECw}), \mathrm{pH}$ and concentration of major and minor and trace constituents. The total dissolved solid (TDS) was calculated from the electrical conductivity of the groundwater $(\mathrm{ECw})$, the total hardness $(\mathrm{TH})$, from the concentration of $\mathrm{Ca}$ and $\mathrm{Mg}$. Alkalinity was calculated from the concentration of the $\mathrm{HCO}_{3}$ as $\mathrm{CaCO}_{3}$ and $\mathrm{pH}$. The physical parameters such as the temperature, $\mathrm{ECw}$ and $\mathrm{pH}$ were measured insitu using standard equipment (Century Water Analysis Kit).

Total hardness $(\mathrm{TH})=2.5 \mathrm{Ca}^{2+}+4.1 \mathrm{Mg}^{2+} \ldots$

Where: $\mathrm{TH}, \mathrm{Ca}$ and $\mathrm{Mg}$ are measured in milligrams per liter and the ratios in equivalent weights (Fournier, 1981).

An approximate relation for most natural groundwater in range of 100 to 5000 micro siemens per centimeter are stated below were used to determine the total dissolved solids (TDS) of the groundwater samples (Todd, 2005).

$1 \mathrm{meq} / \mathrm{l}$ of cations $=100 \mu \mathrm{S} / \mathrm{cm}$ and $1 \mathrm{mg} / \mathrm{l}=$

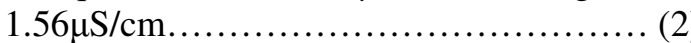

If all of the alkalinity in the sample is a result of inorganic carbon species, the distribution of these species between bicarbonate and carbonate can be calculated using the equilibrium constants for the speciation reaction and the measured $\mathrm{pH}$ of the solution with the following equation (Deutsch, 1997). 
Alkalinity $\left(\mathrm{mg} / \mathrm{l} \mathrm{CaCO}_{3}\right)=\left[\mathrm{HCO}_{3}^{-}\right] \mathrm{mg} / \mathrm{l} \times(1+$ $\left.\underline{2 \times 10^{-10.3}}\right) \times 50 / 61$

$10^{-\mathrm{pH}}$

\section{Data analyses}

SPSS 15.0 version software was used to carry out standard statistical analysis for: minimum, maximum, mean, standard deviation and also to produce graphs of the chemical parameters of the groundwater and rock samples.

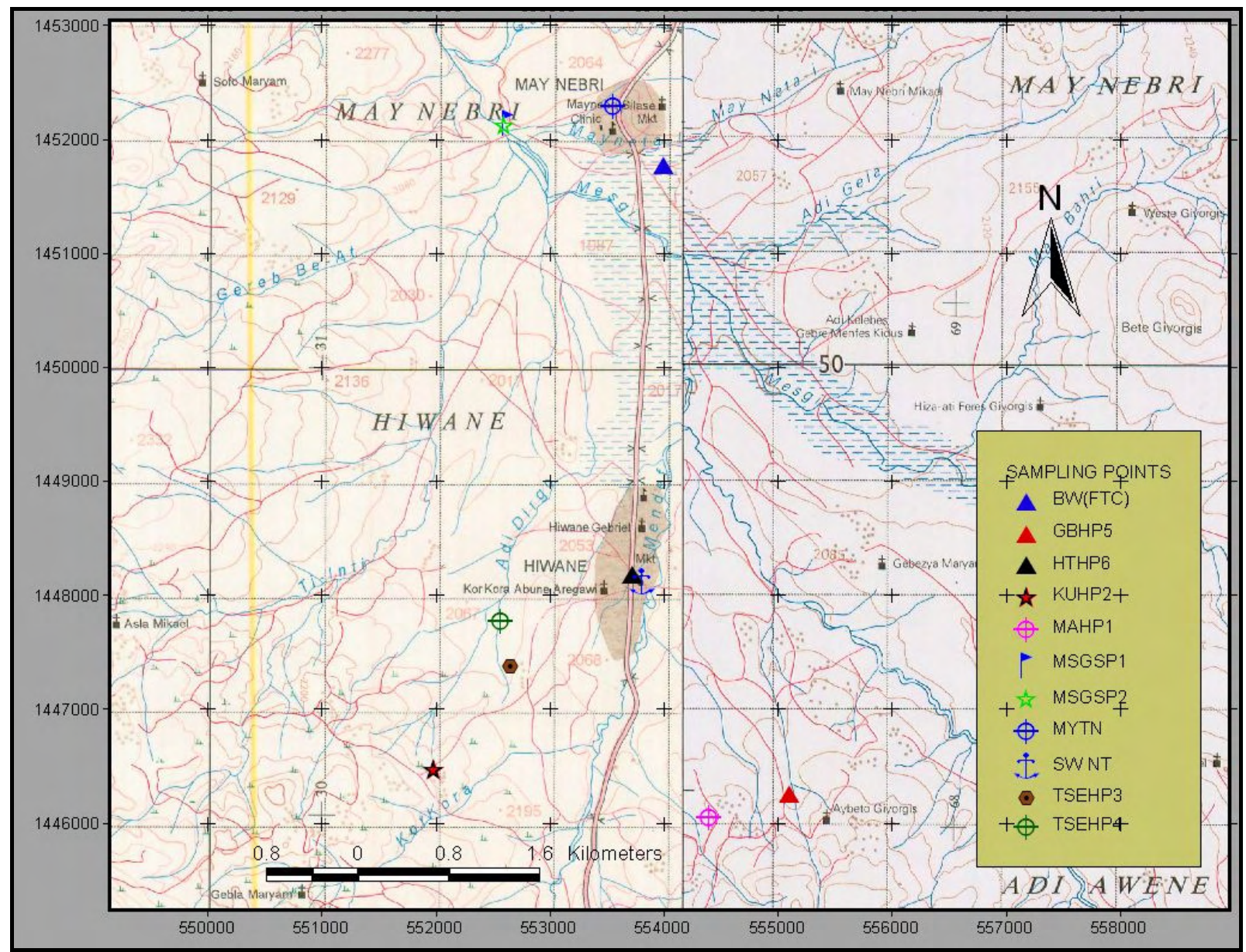

Figure 2 Sampling locations of groundwater and rock samples

\section{Result and Discussion}

\section{Groundwater analysis}

\section{Cations and Anions of the Groundwater} Samples

The concentration of the major cations and anions varied widely. Concentration of $\mathrm{Ca}^{2+}, \mathrm{Mg}^{2+}$, $\mathrm{Na}^{+}$and $\mathrm{K}^{+}$varied from $84 \mathrm{mg} / \mathrm{l}$ at SWNT to 412 $\mathrm{mg} / \mathrm{l}$ at GBHP5 and MSGSP2, from 96mg/l at KUHP2 to $211.2 \mathrm{mg} / 1$ at MSGSP1, from $19.09 \mathrm{mg} / 1$ at KUHP2 to $43.93 \mathrm{mg} / 1$ at MSGSP1, from $2.34 \mathrm{mg} / 1$ at MAHP1 to $51.09 \mathrm{mg} / 1$ at GBHP5, respectively (Table 1 and Figure 3). Concentrations of major anions also varied largely. Concentrations of $\mathrm{HCO}_{3}{ }^{-}$varied from $244 \mathrm{mg} / \mathrm{l}$ of MSGSP2 to $585.6 \mathrm{mg} / \mathrm{l}$ at HTHP6, $\mathrm{Cl}^{-}$ varied from $71 \mathrm{mg} / \mathrm{l}$ at MAHP1 to $340.8 \mathrm{mg} / 1$ at 
MSGSP2, $\quad \mathrm{SO}_{4}{ }^{2-}$ ranged from $49.49 \mathrm{mg} / \mathrm{l}$ in MAHP1 up to $122.5 \mathrm{mg} / \mathrm{l}$ of BW(FTC) (Table 1 and Figure 4).

Concentrations of $\mathrm{Na}^{+}$and $\mathrm{SO}_{4}{ }^{2-}$ of all the groundwater samples were $<200 \mathrm{mg} / \mathrm{l}$ and $<300 \mathrm{mg} / \mathrm{l}$ and concentrations of $\mathrm{Mg}^{2+}$ and $\mathrm{Cl}^{-}$were $>50 \mathrm{mg} / \mathrm{l}$ and $>10 \mathrm{mg} / \mathrm{l}$ of the concentration levels in natural water. One, three and four groundwater samples had concentration values of $\mathrm{Ca}^{2+}, \mathrm{HCO}_{3}{ }^{-}$ and $\mathrm{K}^{+}$, respectively found $<100 \mathrm{mg} / 1,<500 \mathrm{mg} / 1$ and $<10 \mathrm{mg} / 1$ the concentration levels in natural water while the remaining groundwater samples were above concentration levels in natural water Todd (2005).

\section{Electrical conductivity of groundwater (ECw)}

The electrical conductivity of the groundwater samples ranged from $0.88 \mathrm{dS} / \mathrm{m}$ to $3.01 \mathrm{dS} / \mathrm{m}$ at $25^{\circ} \mathrm{C}$ through the sample codes KUHP2 to GBHP5, respectively (Table 1). The high ECw in the GBHP5 indicates that, there are high amounts of dissolved solids. These dissolved solids come from the soluble rocks particularly Shale and the Micritic limestone which are dominant in the area. Since EC is directly related to TDS, the locations showing minimum and maximum values were observed at KUHP2 and GBHP5 for both parameters EC and TDS. Hence, according to Driscoll (1986), the ECw of 6 groundwater samples were found within the good water class while the remaining 4 groundwater samples were found within the fair water class for the $\mathrm{ECW}$ between $0.7-1.5 \mathrm{dS} / \mathrm{m}$ and $1.5-3.7 \mathrm{dS} / \mathrm{m}$, respectively.

\section{Total dissolved solids (TDS)}

The Total Dissolved Solids in the groundwater samples ranged from $564.10 \mathrm{mg} / \mathrm{l}$ to $1929.48 \mathrm{mg} / \mathrm{l}$ at KUHP2 and GBHP5, respectively (Table 1 and Figure 5). Based on the WHO (2004), the groundwater samples are classified in to four categories. Out of the 11 groundwater samples only 1 is categorized as good $(300-600 \mathrm{mg} / \mathrm{l}), 4$ are fair $(600-900 \mathrm{mg} / \mathrm{l})$ and 1 is poor $(900-$ $1200 \mathrm{mg} / \mathrm{l}$ ) and the remaining 4 are unacceptable $(>1200 \mathrm{mg} / \mathrm{l})$.
The minimum amount is observed at KUHP2 which was taken from a spring originating from basalt and limestone contact point and the maximum amount is observed at GBHP5 which was taken from Shale and Micritic limestone intercalation. These dissolved solids are results of the soluble rocks.

According to Freeze and Cherry (1979), six groundwater samples were considered as fresh groundwater and 4 groundwater samples were considered as brackish groundwater.

\section{Total Hardness}

The total hardness of groundwater samples varied from $683.44 \mathrm{mg} / \mathrm{l}$ to $1768.32 \mathrm{mg} / \mathrm{l}$ (Table 1 and Figure 5). The lower value at MAHP1 was found from the contact spring of the basalt and limestone and the higher value at GBHP5 was found from the thick shale and thin limestone intercalation. Due to the chemical composition of the micritic limestone dominantly found in this area the $\mathrm{Ca}$ and $\mathrm{Mg}$ content of the groundwater becomes high hence it is very hard. Generally, all the groundwater samples of the study area were found within the class of very hard water as TDS values $\geq 300 \mathrm{mg} / 1$, Sawyer and McCarty, 1967. Unlike to this study 12 out of 14 groundwater samples analyzed were found soft while the remaining 2 were hard water in the study conducted in Gubrunde and Environs, Northern Nigeria (Arabi et al., 2010).

\section{Alkalinity}

Alkalinity was calculated using the above formula and the computed values ranged from $200.65 \mathrm{mg} / \mathrm{l}$ of $\mathrm{CaCO} 3$ at MSGSP1 $-480.12 \mathrm{mg} / \mathrm{l}$ of $\mathrm{CaCO} 3$ at HTHP6 (Table 1 and Figure 5). All the groundwater samples of the study area exhibit alkalinity values above the permissible limit of $120 \mathrm{mg} / \mathrm{L}$ (WHO, 2008). This may be due to the dissolution of crystalline limestone in the in the study area. It may also be noted that in polluted waters, other negative ions like $\mathrm{PO} 4$, NO3 may contribute to alkalinity (NAS, 1974). 
pH

The groundwater of the study area was found basic its $\mathrm{pH}$ values ranged from 6.84 to 7.43 . The lowest $\mathrm{pH}$ was measured at HTHP6 and the highest $\mathrm{pH}$ was measured at sample MSGSP2 (Table 1). The groundwater samples were found within the Secondary Maximum Contaminant Level (SMCL) for $\mathrm{pH}$ is 6.5 to $8.5 \mathrm{on} \mathrm{pH}$ scale as established by the APHA, (2005).

\section{Groundwater Types}

Totally four groundwater types were identified: $\mathrm{Mg}-\mathrm{Ca}-\mathrm{HCO}_{3}, \mathrm{Mg}-\mathrm{Ca}-\mathrm{HCO} 3-\mathrm{Cl}, \mathrm{Ca}-$ $\mathrm{Mg}-\mathrm{HCO}_{3}$ and $\mathrm{Mg}-\mathrm{HCO}_{3}$ type. Out of these the dominant one is $\mathrm{Mg}-\mathrm{Ca}-\mathrm{HCO}_{3}$. This groundwater type was found in 7 of the groundwater samples out of the 11. Generally, the groundwater of the study area is dominated by the major ionic components. Unlikely, two water types $\mathrm{Ca}-\mathrm{Mg}-$ $\mathrm{HCO}_{3}$ and $\mathrm{Ca}-\mathrm{Mg}-\mathrm{SO}_{4}-\mathrm{Cl}$ were found in the groundwater samples of Port Harcourt City, Southern Nigeria (Nwankwoala and Udom, 2011).

\section{Trace constituents of the groundwater samples}

Trace elements are contributed to groundwater from a variety of natural and anthropogenic sources. Once liberated into groundwater, element distributions are continually modified by complex geochemical and biological processes (Newcomb and Rimstidt, 2002).

The concentrations of $\mathrm{Pb}, \mathrm{Co}, \mathrm{Cu}, \mathrm{Zn}$, and $\mathrm{Mn}$ of groundwater samples varied from undetectable to $0.06 \mathrm{mg} / \mathrm{l}$ at two samples TSEHP3 and HTHP6, from undetectable to $0.12 \mathrm{mg} / \mathrm{l}$ at GBHP5, from $0.06 \mathrm{mg} / 1$ at MAHP1 and BW (FTC) to $0.09 \mathrm{mg} / 1$ at KUHP2, MSGSP1 and MSGSP2, from undetectable to $0.29 \mathrm{mg} / \mathrm{l}$ at KUHP2 and from undetectable to $0.13 \mathrm{mg} / 1$ at GBHP5, respectively (Table 2).

The concentration of the trace elements $\mathrm{Cu}, \mathrm{Ni}$ and $\mathrm{Mn}$ for the groundwater samples of the study area were found within the maximum permissible limit of drinking water, which is $2 \mathrm{mg} / 1,0.07 \mathrm{mg} / \mathrm{l}$ and $0.4 \mathrm{mg} /$, respectively. However, $60 \%$ of the $\mathrm{Pb}$ concentration of the groundwater samples was found within the permissible limit, $0.01 \mathrm{gm} / 1$ while the remaining $40 \%$ was found above the maximum permissible limit of drinking water set by WHO (2008).

\section{Rock Analysis \\ Major cations and anions of rock samples}

Concentrations major cations of $\mathrm{Ca}^{2+}, \mathrm{Mg}^{2+}$, $\mathrm{Na}^{+}$and $\mathrm{K}^{+}$of rock samples of the study area varied from $2586.4 \mathrm{ppm}$ at TS to $28540 \mathrm{ppm}$ at FTC, from $2575.8 \mathrm{ppm}$ at TS to $5289.6 \mathrm{ppm}$ at FTC, from $28.83 \mathrm{ppm}$ at MA to $6134.9 \mathrm{ppm}$ at $\mathrm{GB}$, from $190.3 \mathrm{ppm}$ at MA to $2379 \mathrm{ppm}$ at GB, respectively (Table 3 and Figure 6). Concentrations major anions of $\mathrm{HCO}_{3}^{-}$varied from 293.74ppm at MSG to 3717.6ppm at TS, $\mathrm{Cl}^{-}$varied from $433.1 \mathrm{ppm}$ at TS to $1143.1 \mathrm{ppm}$ at MSG, $\mathrm{SO}_{4}{ }^{2-}$ ranged from $2787.8 \mathrm{ppm}$ at TS to 27849.6ppm at FTC (Table 3 and Figure 7).

\section{Trace elements of rock samples}

The concentrations of $\mathrm{Pb}, \mathrm{Co}, \mathrm{Cu}, \mathrm{Zn}, \mathrm{Mn}$, $\mathrm{Ni}$ and $\mathrm{Fe}$ varied from undetectable to $2 \mathrm{ppm}$ at two samples GB and FTC, 9ppm at all samples to $198 \mathrm{ppm}$ at MSG, from 5ppm at FTC $-25 \mathrm{ppm}$ at MSG, from 5ppm at MA to 60ppm at FTC and from 36ppm at MA to 421ppm at FTC, from less than 2ppm at MA to $105 \mathrm{ppm}$ at MSG and from $1190 \mathrm{ppm}$ at MA to $42400 \mathrm{ppm}$ at TS, respectively (Table 3). According to Klimasauskas et al., (2007) the concentration of $\mathrm{Pb}, \mathrm{Cu}$ and $\mathrm{Ni}$, ranged from $0.5-10,000 \mathrm{ppm}$, the concentration of Co ranged from 0.1 $10,000 \mathrm{ppm}$, the concentration of $\mathrm{Zn}$ ranged from $1-10,000 \mathrm{ppm}$ and the concentration of $\mathrm{Mn}$ ranged from $5-10,000 \mathrm{ppm}$ hence the concentrations of these elements in the study area were found within this bound.

\section{Rock - Water Interaction}

The predominant major cations trend in the study area was $\mathrm{Ca}^{2+}>\mathrm{Mg}^{2+}>\mathrm{Na}^{+}>\mathrm{K}^{+}$and the abundance of the major anions was in the following order: $\mathrm{HCO}_{3}^{-}>\mathrm{Cl}^{-}>\mathrm{SO}_{4}{ }^{2-}$ while carbonates remain nil throughout the groundwater samples. Similarly the abundance of cations in Port Harcourt City, Southern Nigeria was in the following order of $\mathrm{Ca}^{2+}>\mathrm{Mg}^{2+}>\mathrm{Na}^{+}>\mathrm{K}^{+}$and anions were also in the order of $\mathrm{HCO}_{3}{ }^{-}>\mathrm{Cl}^{-}>$ 
$\mathrm{SO}_{4}{ }^{2-}>\mathrm{NO}_{3}{ }^{-}$where calcium is the dominant cation while bicarbonate dominates the anionic components of the groundwater (Nwankwoala and Udom, 2011). Similarly, the carbonate concentrations of the study area remains zero as in the groundwater samples of Hantebet watershed in the application of water quality index to assess suitability of groundwater quality for drinking purposes, Tigray, Northern Ethiopia Gebrehiwot et al., (2011).

The results of the chemical and mineralogical analysis of the rock samples show that the dominant major cations were found in the order of $\mathrm{Ca}^{2+}>\mathrm{Mg}^{2+}>\mathrm{Na}^{+}>\mathrm{K}^{+}$and the predominance of major anions were in the of $\mathrm{HCO}_{3}{ }^{-}>\mathrm{SO}_{4}{ }^{2-}>\mathrm{Cl}^{-}$ (Table 1 and 3).

\section{Conclusion}

The predominant major cation trends in both the groundwater and rock samples of the study area was found similar in the order of $\mathrm{Ca}^{2+}>\mathrm{Mg}^{2+}$ $>\mathrm{Na}^{+}>\mathrm{K}^{+}$and also similar major anion trends in both the groundwater and rock samples was observed. Therefore, from the results obtained it is possible to conclude that the high concentration of cations, anions, trace elements and dissolved solids in the groundwater samples come from the soluble rock units and hence the chemistry of the groundwater samples was affected by the chemical and mineralogical composition of the rocks.

From the results obtained from the rock sample analysis a large amount of calcium, magnesium and bicarbonate were found in the limestone both in the crystalline and micritic while relatively small amount of sodium and potassium were obtained. But in the shale samples relatively large amounts of sodium and potassium were found. Then, it was concluded that the source for large amount total hardness, TDS and alkalinity were largely the micritic limestone and some extent the crystalline limestone. But in the shale the dominant components are silica and iron which are less soluble in groundwater.

The sulphate in the groundwater is limited, because of the limited amount of gypsum and its less solubility.

\section{Recommendation}

The causes for the quality problems are the micritic and to some extent the crystalline and shale units. Therefore, any type of drilling for domestic purposes should be done outside of these geologic units. Hence, to supply adequate and good quality of groundwater for the people of Hiwanie town and its surrounding areas it is better to construct wells in the sandstone, basalt and dolerite because these units have considerable good quality, because of the less solubility nature of the rocks.

\section{References}

APHA (2005). American Public Health Association, American Water Works Association and World Environment Federation, "Standard Methods for Examination of Water and Wastewater," 21st Edition, American Public Health Association, Washington DC, USA.

Arabi, S. A., Funtua, I. I., Alagbe, S. A., Zabosrki, P. and Dewu, B. (2010). Investigation of groundwater quality for domestic and irrigation purposes around Gubrunde and Environs, Northern Nigeria. Journal of American Science, 6(12), 664-672.

Deutsch, W. J. (1997). Groundwater Geochemistry: Fundamentals and applications to contamination. Lewis publishers, New York.

Driscoll, F.G. (1986). Groundwater and Wells. Johnson Screens, Minnesota, USA.

Eaton, A. D., Clesceri L. S. and Greenberg, A. E. (1998). Standard Method for Examination of Water and Wastewater. American Public Health Association, American Water Works Association, Water Environment Federation, 18th Ed., Washington DC., USA.

Fournier, R. O. (1981). Application of water Geochemistry to geothermal exploration and resevior engineering in L. Rybach and L.J.P. Muffler, eds., Geothermal Systems, Principles and Case histories, John Wiley \& Sons, New York. Pp. $109-143$.

Freeze, R. A. and Cherry, J. A. (1979). Groundwater: Prentice-Hall, Englewood Cliffs, New Jersey, USA. PP. 84 - 387.

Gebrehiwot, A. B., Tadesse N. and Jigar E. (2011). Application of water quality index to 
assess suitability of groundwater quality for drinking purposes in Hantebet watershed, Tigray, Northern Ethiopia. ISABB Journal of Food and Agriculture Science, 1(1), 22 - 30.

Klimasauskas, E. P., Miller, M. L., and Bradley, D. C. (2007). Major- and trace-element concentrations in rock samples collected in 2006 from the Taylor Mountains 1:250,000-scale quadrangle, Alaska: U.S. Geological Survey Open-File Report 2007-1386, 6 p. NAS. (1974). Water quality criteria. Nat. Acad. Sci., 23: pp 105. Newcomb, W. D. and Rimstidt, J. D. (2002). Trace Element Distribution assessment Using Public Domain Data. Applied Geochemistry, 17: 49-57.

Nwankwoala, H. O. and Udom, G. J. (2011). Studies on Major Ion Chemistry and Hydrogeochemical Processes of Groundwater in
Port Harcourt City, Southern Nigeria. Journal of Spatial Hydrology, 11(1), 34-40.

Sawyer, C. N. and McCarty, P. L. (1967). Chemistry of salinity engineers, $2^{\text {nd }}$ ed., McGraw-Hill, New York.

Todd, D. K. (2005). Groundwater Hydrology. John Wiley and Sons, Inc. New York, USA.

Tolgyessy, J. (1993). Chemistry and Biology of Water, Air and Soil Environmental Aspects. Elsevier, Amsterdam.

WHO. (2004). World Health Organization, Guidelines for Drinking-Water Quality, 3rd Edition, Geneva, Switzerland.

WHO. (2008). World Health Organization, Guidelines for Drinking-Water Quality, 3rd Edition, Vol. 1. Geneva, Switzerland.

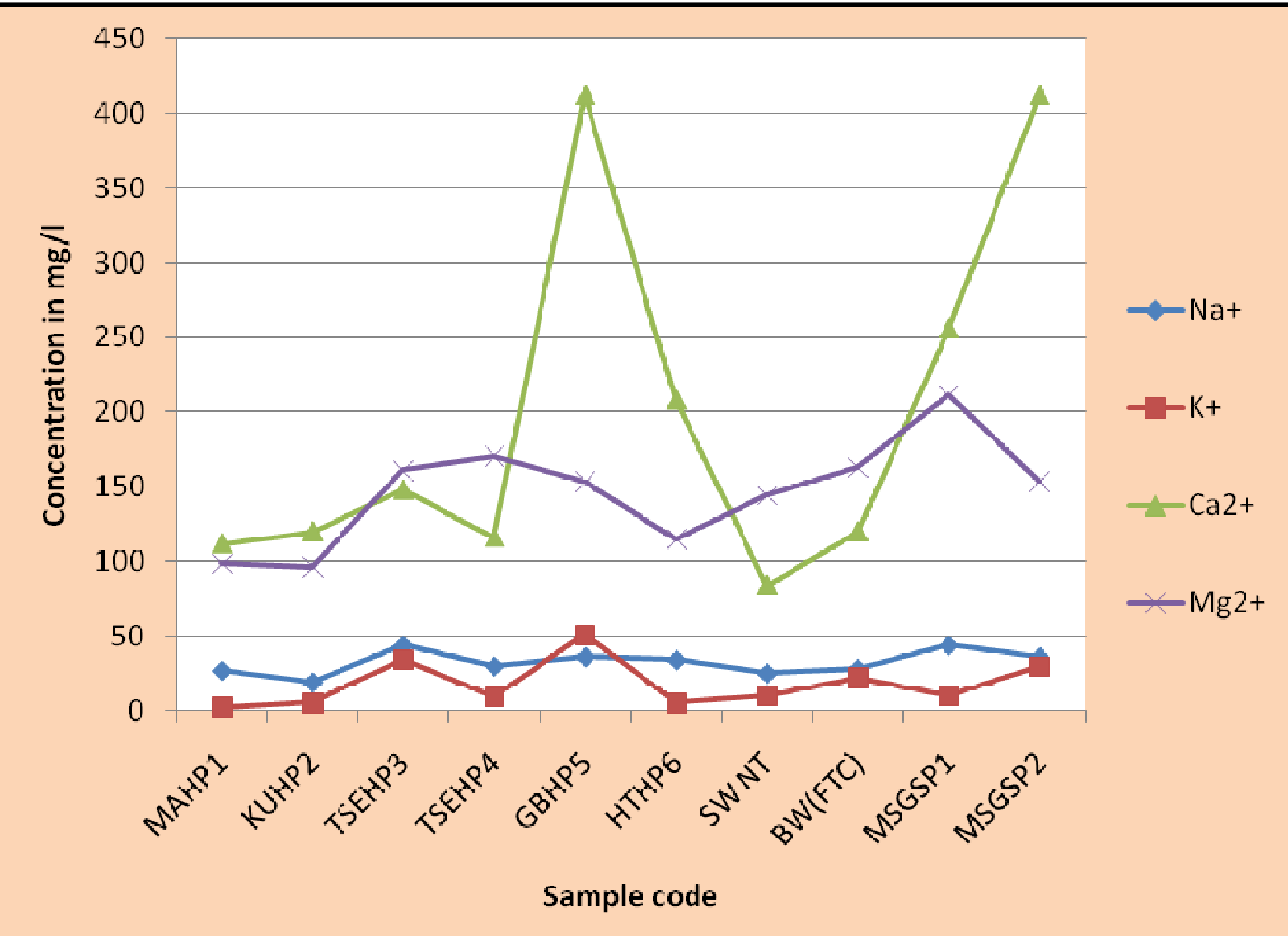

Figure 3 Concentration of major cations of the groundwater samples 


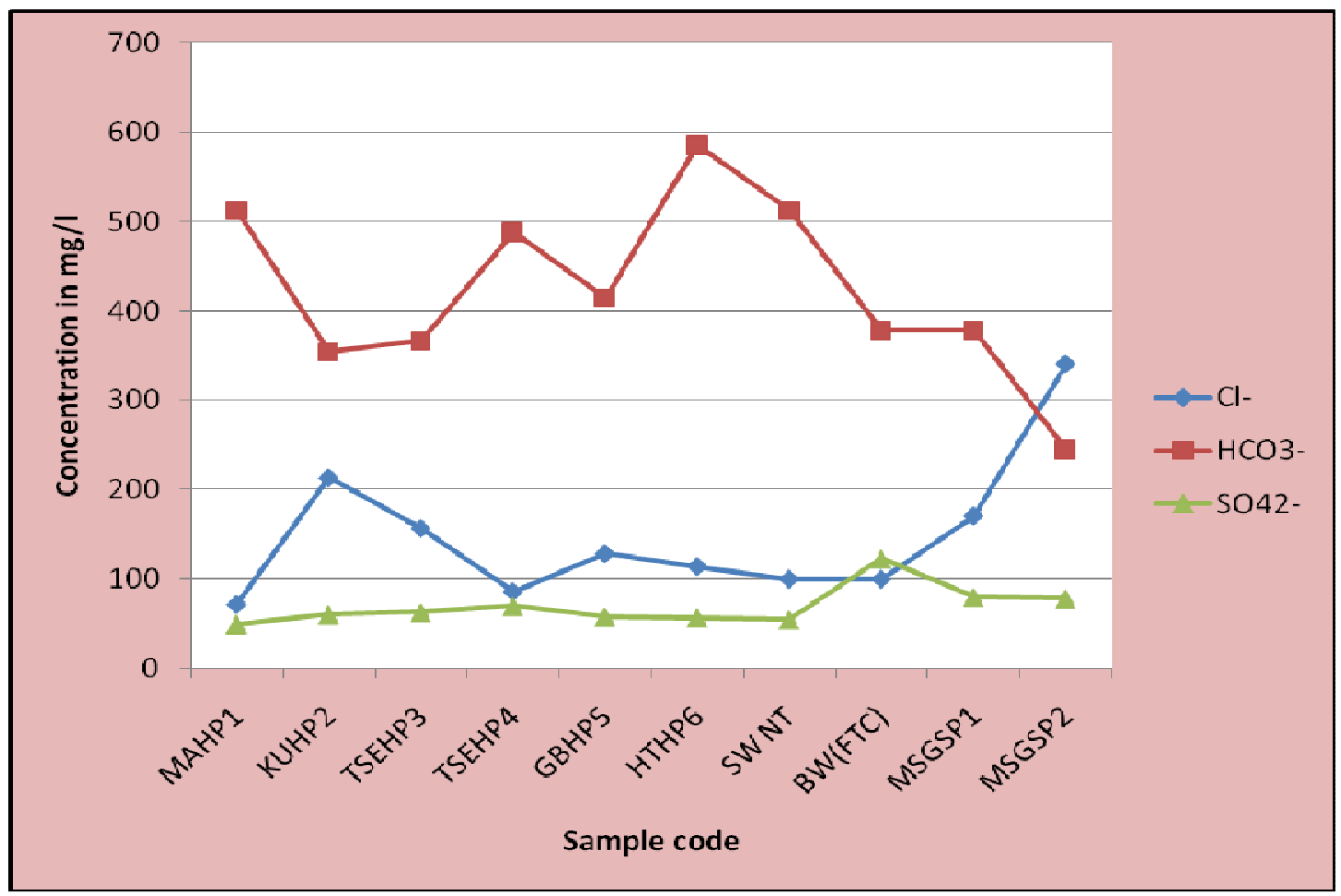

Figure 4 Concentration of major anions of groundwater samples

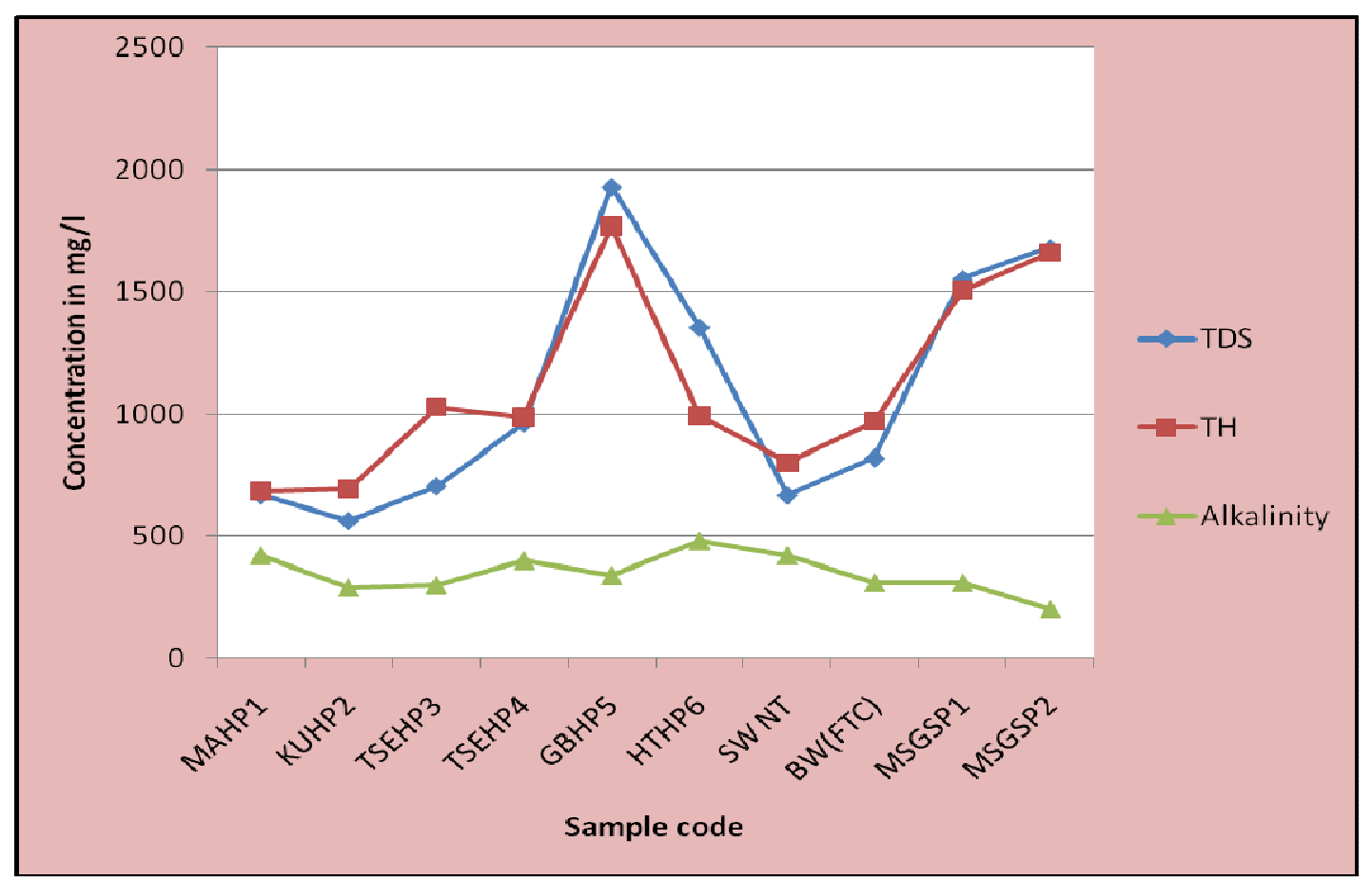

Figure 5 Graph representing the total hardness, alkalinity and TDS of the groundwater samples 


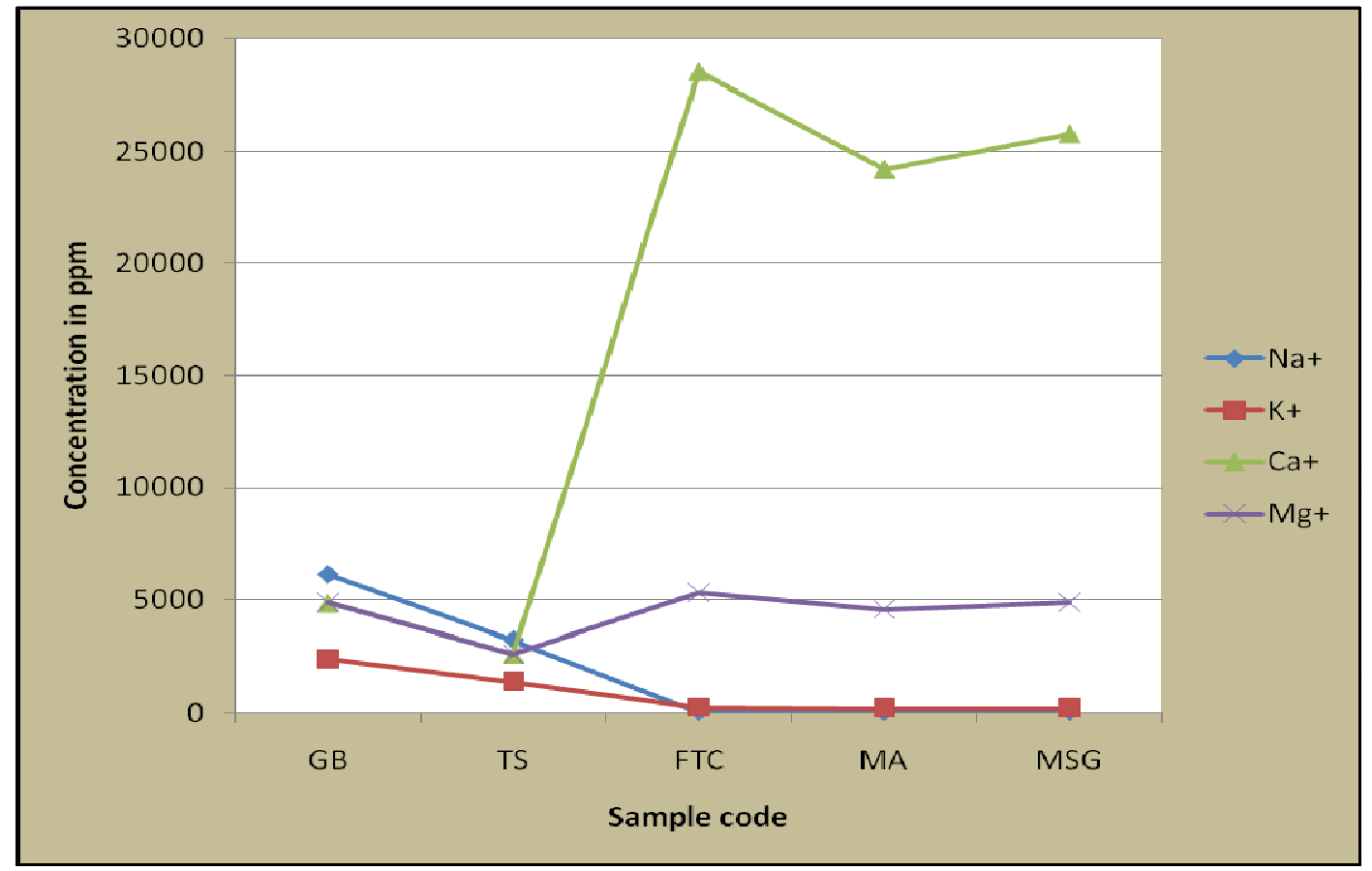

Figure 6 Concentration of major cations of rock samples

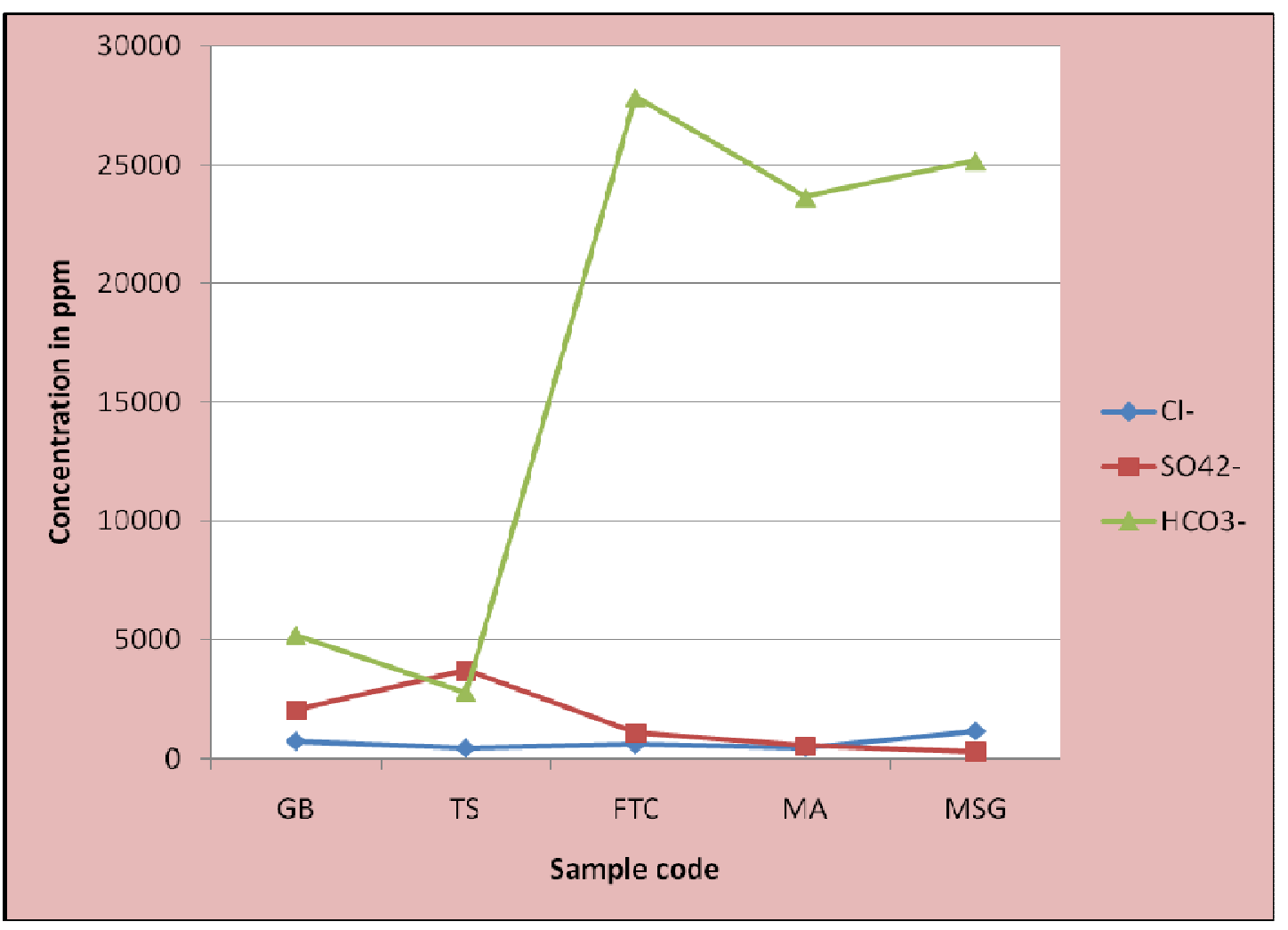

Figure 7 Concentration of major anions of rock samples 
Table 1 The major and minor ions, $\mathrm{pH}$, TDS and $\mathrm{ECw}$ determined in the groundwater samples of study area

\begin{tabular}{|c|c|c|c|c|c|c|c|c|c|c|c|c|c|c|c|c|}
\hline \multirow{2}{*}{$\begin{array}{l}\text { Sample } \\
\text { code }\end{array}$} & \multicolumn{3}{|c|}{ GPS location (in UTM) } & \multirow{2}{*}{$\begin{array}{c}\mathrm{EC} \\
(\mathrm{dS} / \mathrm{m})\end{array}$} & \multirow[t]{2}{*}{$\mathrm{pH}$} & \multirow{2}{*}{$\begin{array}{l}\text { Temp } \\
\left({ }^{\circ} \mathrm{C}\right)\end{array}$} & \multirow{2}{*}{$\begin{array}{l}\mathrm{Na}^{+} \\
\mathrm{mg} / \mathrm{l}\end{array}$} & \multirow{2}{*}{$\begin{array}{c}\mathrm{K}^{+} \\
\mathrm{mg} / \mathrm{l}\end{array}$} & \multirow{2}{*}{$\begin{array}{l}\mathrm{Ca}^{2+} \\
\mathrm{mg} / 1\end{array}$} & \multirow{2}{*}{$\begin{array}{l}\mathrm{Mg}^{2+} \\
\mathrm{mg} / 1\end{array}$} & \multirow{2}{*}{$\begin{array}{c}\mathrm{Cl}^{-} \\
\mathrm{mg} / \mathrm{l}\end{array}$} & \multirow{2}{*}{$\begin{array}{c}\mathrm{HCO}_{3}^{-} \\
\mathrm{mg} / \mathrm{l}\end{array}$} & \multirow{2}{*}{$\begin{array}{l}\mathrm{SO}_{4}{ }^{2-} \\
\mathrm{mg} / \mathrm{l}\end{array}$} & \multirow{2}{*}{$\begin{array}{l}\text { TDS } \\
(\mathrm{mg} / \mathrm{l})\end{array}$} & \multirow{2}{*}{$\begin{array}{c}\mathrm{TH} \\
\mathrm{mg} / \mathrm{l}\end{array}$} & \multirow{2}{*}{$\begin{array}{c}\text { Alkalinity } \\
\mathrm{mg} / \mathrm{l}\end{array}$} \\
\hline & $\begin{array}{l}\text { UTME } \\
(\mathrm{m})\end{array}$ & $\begin{array}{l}\text { UTMN } \\
\text { (m) }\end{array}$ & $\begin{array}{l}\text { Elev } \\
(\mathrm{m})\end{array}$ & & & & & & & & & & & & & \\
\hline MAHP1 & 554398 & 1446044 & 2215 & 1.04 & 7.1 & 21.3 & 26.91 & 2.34 & 112 & 98.4 & 71 & 512.4 & 49.49 & 666.66 & 683.44 & 420 \\
\hline KUHP2 & 551983 & 1446472 & 2232 & 0.88 & 7.39 & 21.1 & 19.09 & 5.46 & 120 & 96 & 213 & 353.8 & 60.27 & 564.1 & 693.6 & 290.6 \\
\hline TSEHP3 & 552652 & 1447377 & 2074 & 1.1 & 7.19 & 22 & 43.93 & 34.32 & 148 & 160.8 & 156.2 & 366 & 62.72 & 705.12 & 1029.28 & 300.72 \\
\hline TSEHP4 & 552568 & 1447769 & 2087 & 1.5 & 7.37 & 22.3 & 29.9 & 9.36 & 116 & 170.4 & 85.2 & 488 & 69.58 & 961.53 & 988.64 & 400.78 \\
\hline GBHP5 & 555107 & 1446263 & 2064 & 3.01 & 6.89 & 23.1 & 36.11 & 51.09 & 412 & 153.6 & 127.8 & 414.8 & 57.82 & 1929.48 & 1768.32 & 340.13 \\
\hline HTHP6 & 553729 & 1448177 & 2061 & 2.11 & 6.84 & 22.6 & 34.04 & 5.46 & 208 & 115.2 & 113.6 & 585.6 & 56.84 & 1352.56 & 992.32 & 480.12 \\
\hline SW NT & 553812 & 1448121 & 2025 & 1.04 & 7.25 & 21.4 & 25.07 & 10.14 & 84 & 144 & 99.4 & 512.4 & 54.39 & 666.66 & 800.4 & 420.16 \\
\hline BW(FTC) & 554000 & 1451777 & 2016 & 1.28 & 7.2 & 21.2 & 28.06 & 22.23 & 120 & 163.2 & 99.4 & 378.2 & 122.5 & 820.51 & 969.12 & 310.51 \\
\hline MSGSP1 & 552633 & 1452152 & 1968 & 2.42 & 7.09 & 23.3 & 43.93 & 10.14 & 256 & 211.2 & 170.4 & 378.2 & 79.87 & 1551.28 & 1505.92 & 310.74 \\
\hline MSGSP2 & 552601 & 1452117 & 1965 & 2.62 & 7.43 & 23.5 & 36.11 & 30.01 & 412 & 153.6 & 340.8 & 244 & 77.91 & 1679.48 & 1659.76 & 200.61 \\
\hline Minimum & & & & 0.88 & 6.84 & 21.1 & 19.09 & 2.34 & 84 & 96 & 71 & 244 & 49.49 & 564.1 & 683.44 & 200.61 \\
\hline Maximum & & & & 3.01 & 7.43 & 23.5 & 43.93 & 51.09 & 412 & 211.2 & 340.8 & 585.6 & 122.5 & 1929.48 & 1768.32 & 480.12 \\
\hline Average & & & & 1.7 & 7.18 & 22.2 & 32.32 & 18.06 & 198.8 & 146.6 & 147.7 & 423.3 & 69.14 & 1089.74 & 1109.08 & 347.437 \\
\hline $\begin{array}{l}\text { Standard } \\
\text { deviation }\end{array}$ & & & & 0.77 & 0.20 & 0.92 & 8.04 & 15.92 & 123.30 & 35.26 & 80.38 & 100.45 & 21.19 & 495.11 & 394.19 & 82.15 \\
\hline
\end{tabular}

N.B.: TDS=Total Dissolved Solids, TH= Total Hardness, Elev $=$ Elevation and Temp=Temperature 
Table 2 Concentration of trace cations of the analyzed groundwater samples (mg/l)

\begin{tabular}{|l|l|l|l|l|l|l|}
\hline Sample ID & $\mathrm{Pb}$ & $\mathrm{Co}$ & $\mathrm{Ni}$ & $\mathrm{Cu}$ & $\mathrm{Zn}$ & $\mathrm{Mn}$ \\
\hline MAHP1 & $<0.02 \mathrm{U}$ & $<0.02 \mathrm{U}$ & $<0.02 \mathrm{U}$ & 0.06 & $<0.02 \mathrm{U}$ & $<0.02 \mathrm{U}$ \\
\hline KUHP2 & 0.02 & 0.07 & $<0.02 \mathrm{U}$ & 0.09 & 0.29 & 0.02 \\
\hline TSEHP3 & 0.06 & 0.02 & $<0.02 \mathrm{U}$ & 0.08 & 0.02 & $<0.02 \mathrm{U}$ \\
\hline TSEHP4 & $<0.02 \mathrm{U}$ & $<0.02 \mathrm{U}$ & $<0.02 \mathrm{U}$ & 0.08 & $<0.02 \mathrm{U}$ & $<0.02 \mathrm{U}$ \\
\hline GBHP5 & $<0.02 \mathrm{U}$ & 0.12 & $<0.02 \mathrm{U}$ & 0.08 & $<0.02 \mathrm{U}$ & 0.13 \\
\hline HTHP6 & 0.06 & 0.09 & $<0.02 \mathrm{U}$ & 0.08 & 0.10 & 0.11 \\
\hline SWNT & $<0.02 \mathrm{U}$ & 0.10 & $<0.02 \mathrm{U}$ & 0.08 & $<0.02 \mathrm{U}$ & 0.02 \\
\hline BW(FTC) & $<0.02 \mathrm{U}$ & $<0.02 \mathrm{U}$ & $<0.02 \mathrm{U}$ & 0.06 & 0.03 & 0.02 \\
\hline MSGSP1 & $<0.02 \mathrm{U}$ & 0.08 & $<0.02 \mathrm{U}$ & 0.09 & $<0.02 \mathrm{U}$ & 0.02 \\
\hline MSGSP2 & 0.02 & 0.08 & $<0.02 \mathrm{U}$ & 0.09 & $<0.02 \mathrm{U}$ & 0.02 \\
\hline
\end{tabular}

N.B.: U=Undetectable (below 0.02mg/l) 
Table 3. The major, minor and trace elements of rock samples collected from the study area (ppm)

\begin{tabular}{|l|l|l|l|l|l|l|l|l|l|l|l|l|l|l|}
\hline $\begin{array}{l}\text { Sample } \\
\text { Code }\end{array}$ & $\mathrm{Na}^{+}$ & $\mathrm{K}^{+}$ & $\mathrm{Ca}^{2+}$ & $\mathrm{Mg}^{2+}$ & $\mathrm{Cl}^{-}$ & $\mathrm{SO}_{4}^{2-}$ & $\mathrm{HCO}_{3}^{-}$ & $\mathrm{Cu}$ & $\mathrm{Zn}$ & $\mathrm{Ni}$ & $\mathrm{Co}$ & $\mathrm{Mn}$ & $\mathrm{Fe}$ & $\mathrm{Pb}$ \\
\hline GB & 6134.9 & 2379 & 4837.3 & 4857.12 & 724.2 & 2050.08 & 5188 & 7 & 15 & 5 & 9 & 229 & 7930 & 2 \\
\hline TS & 3228.7 & 1378.0 & 2586.4 & 2575.8 & 433.1 & 3717.6 & 2787.8 & 6 & 30 & 12 & 9 & 295 & 42400 & $<2$ \\
\hline FTC & 33.97 & 224.24 & 28540 & 5289.6 & 589.3 & 1083.36 & 27849.6 & 5 & 60 & 3 & 9 & 421 & 8460 & 2 \\
\hline MA & 28.83 & 190.3 & 24220 & 4549.9 & 433.1 & 556.8 & 23633.9 & 8 & 5 & $<2$ & 9 & 36 & 1190 & $<2$ \\
\hline MSG & 30.30 & 200.14 & 25800 & 4846.7 & 1143.1 & 293.74 & 25175.75 & 25 & 35 & 105 & 198 & 119 & 25100 & $<2$ \\
\hline
\end{tabular}

